Nippon Suisan Gakkaishi $\quad \mathbf{5 9 ( 1 ) , 7 - 1 4 ~ ( 1 9 9 3 ) ~}$

\title{
土佐湾のマイワシに拈ける卵母細胞の吸水完了 拉よび産卵開始時刻
}

\author{
森本 晴之 \\ (1992 年 4 月 24 日受付)
} Time of Maximal Oocyte Hydration and Spawning in the Japanese
Sardine in Tosa Bay, Southwestern Japan

Haruyuki Morimoto*z

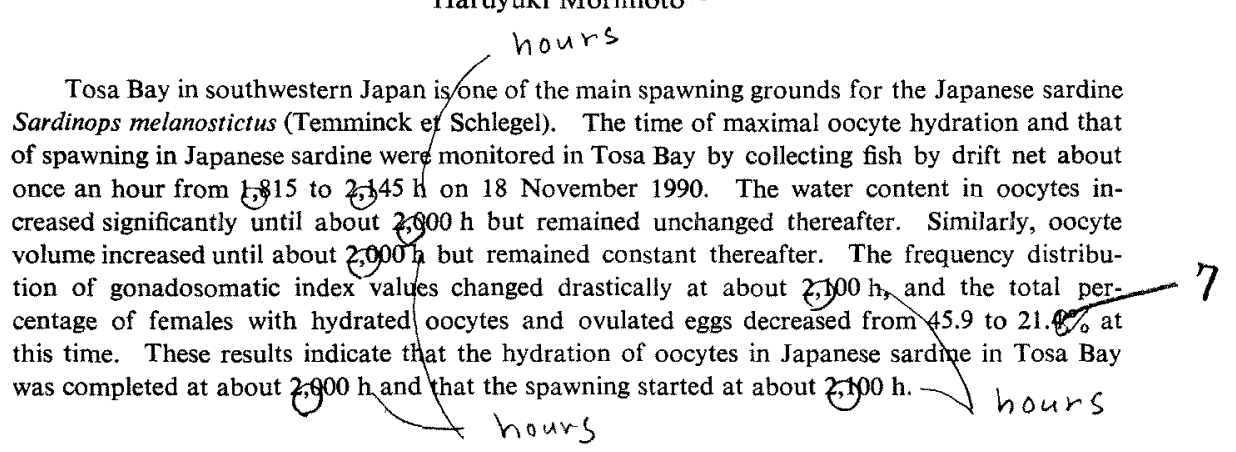

マイワシ Sardinops melanostictus の個体数の変動機 構を解明するためには，一回当たりに産出される畉数を

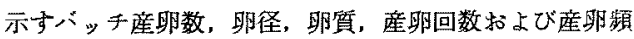
度など再生産能力関する知見が必要とされる。これら についての報告はいくつかみられるが、1-5) それらのは とんどは，いまだ推論の域を出ていない。これらの不明 な点を明らかにするためには，要産䛇活動の日周りズ 厶を把握すること，特に，何時頃に卵母細胞が吸水を完 了して，排卵し，産卵するかを正確に把握する必要があ 吉。

排卵を誘起する一要因と考光られている即母細胞の吸 水過程に関する研究は，イワシ類ではカタクチイワシ Engraulis mordax ${ }^{(0,7)}$ 执よび E. japonicus ${ }^{8, \theta)}$ について の報告がいくつかあるが、マ、イワシについては，見在事 でみられていない。そ机は、マイワシが飼育下では自然 産莭しないためである。10),*3

マイワシの産卵時刻に関する研究には，定期的に採集 した卵の発生 stage を把握し，各 stage に達するまでに
要する時間を水温との風係式から求め, 逆算する方法を

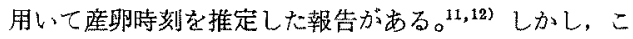
の方法では，産出された卵の东温履歷を正確に求かなり ればならず，その上うにして得られた産楽時刻は誤盖が 比較的大きいと考文られる。しかし，最近，産畉親魚を 用いて直接的儿鷹卵時刻を求わる力法が取入れられ，座 卵の過程で短時間に分泌される卵成熟誘起ステロイドホ

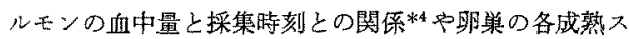

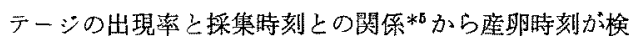
討されている。産畉の開始時刻を正確に求めるには，で きる限り短い時間間隔で定期的に採集した産助親魚の卵 楽を用いて，卵母細胞の吸水から排䀦を経て産卵に至る 過程の経時变化を把握する力法が最良上考えられる。 マイワシ成魚を採集する手段には，釣り漁县と緝漁县 といった2 種類の方法があるが，採集した䀦体の群れ全 体们対する代表性の点からみると後者が優れていると言

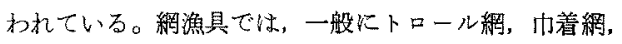
流し網の 3 漁具が用いられるが，イワシ類の上らな橴泳

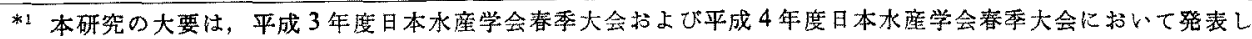
t.

*2 南西海区水産研究所 (Nansei National Fisheries Research Institute, Sanbashidori, Kochi 780, Japan).

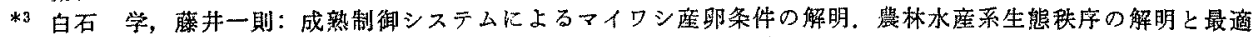
制徆比関する総合研究（パイオコスモス計画）平成元年度研究報告，174-175 (1990).

*4 白石 学：マイワシ親魚の成熟と産卵，浮魚資源一その再生産と加入機權，月刊海洋，24，284-288 (1992).

*5 松浦修平：マイワシの生殖周期，浮魚資源一その再生産と加入機榙，月刊海洋，24，289-294 (1992). 
力の比較的大き顷魚種では，特に産畉期崔魚を採集する 時、トロ一儿網や巾着絧を用いると，産畉直前の倠の過 大サンプリングが生じるといわれている。 ${ }^{13-15)}$ それは率 母細胞の吸水によって睢視魚の曳給回避能力が減少する ことが原因の一つであるとされている。しかし，流し網 の場合，曳絧といら操作がないため，回避能力の䕗いに よる過大サンプリンダはトトロール網や巾着網に比べて 生しにくいと考えられ，探集した個体の個体群への代表 性は比校的高いと考它られる。

本研究では，膺卵期に一定時間間隔で流し緢に上って 採集した倠成魚を用いて，艺の卵策の水分含有率，生殖 腺体重比組成乡吸水した䀦細胞をる雌（以下，吸水 倠; female with hydrated oocytes) および排卵した卵を

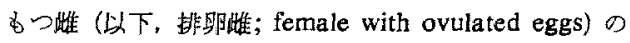
個体数の雙全個体数仁占わる整合の経時变化を調べ，卵 母細胞の吸水完了括よび産莭開始甠刻に関する知見を得 たので報告する。

\section{実 験 方 法}

1990 年 11 月 18 日に, 高知票調查船土佐海洋丸(48

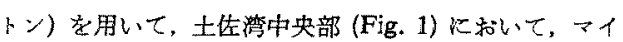
ワシ成魚を採集した。採集には高さ $10 \mathrm{~m}$, 浮子側の長さ $30 \mathrm{~m}$ の流し絧を用いた。をた，用いた流し網は，採集個 体のサイズに偏りが生じないらにするため，網目の大 きさが $38 \mathrm{~mm}, 43 \mathrm{~mm}$ 战よび $48 \mathrm{~mm}$ の絀地を横方向に 慗ぎ合わせたものであった。

採集回数は合計 4 回で, 18 時 15 分, 19 時 5 分, 20 時 10 分敊よび 21 時 10 分に投絧し、浸漬時間は各

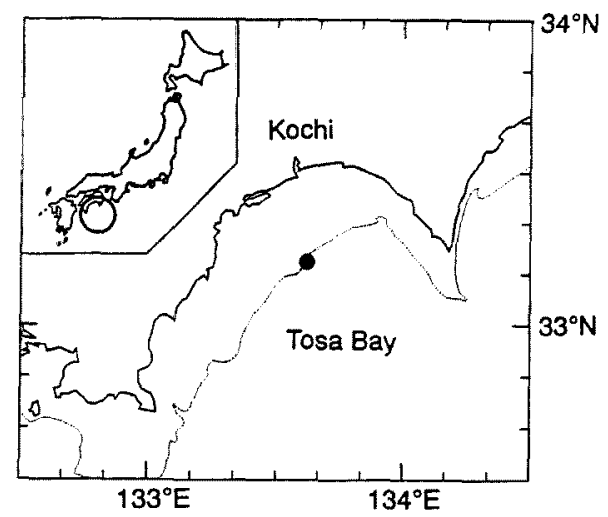

Fig. 1. Sampling location of Japanese sardines. Closed circle, sampling location; dotted line, $200 \mathrm{~m}$ depth contour.
々 30 分間とした。魚群探知機による映像から, 魚群が

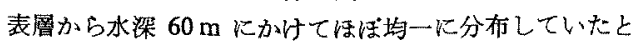
考えられたため，入稀水深は $10 \sim 40 \mathrm{~m}$ の間に設定し た。

採集したマイワシ成魚は採集時刻別に氷藏して持ち帰 り, 倠魚を対潒として, 被鳞体長, 体重 (BW) おょび眀 盖重量 (GW) そ測定し, 生殖腺体重比 (GSI $=(G W / B W)$ ×100)を算出した。また，採集後 10 時間以内に畉策を 摘出し，その一部を5\%ホルマリンで固定し，残りは常 王加熱乾燥法による水分含有率の測定に供した。また，

鳞によって年令を查定した。

吸水した卵母細胞および排卵した畉を保有する㽗果の $5 \%$ ホルマリン固定試料を用いて，湘微訪測装置を装着

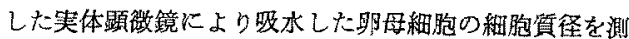
定した。ここで一般に，吸水し，透明化した根は，ほ注 畉黄からなる細胞質を取り团さ細胞膜が卵膜に密着し， 明径二莭黄径とされるが，今回用いた昅水した卵母細胞 は，5\%ホルマリン固定処理によって瞅膜が細胞犋から 若干遊離し，眀膜と細胞質が実体㩆激鏡下で識別できた ため，細胞質径を明黄径とみなして測定した。細胞質径 は長径と短径を測定し，畉母細胞が回転棈円体であると 仮定して即母細胞の体積を求めた。なお，計測は一つの 卵采につき約 50 個の畉母細胞について行った。

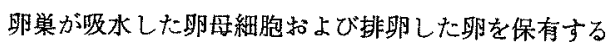
こと洼，母体から採取する時に行った肉眼観察と $5 \%$ 米

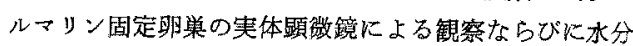
含有率の測定を併用して決定した。水分含有率が $89 \%$ 前 後の那渠が吸水した畉母細胞を保有することは，本研究 とは別に，1989 年 11 月林よび 1990 年 1 月に採集し た倠親魚のブアン固定した即晕を用いて，組織学的検討 によって確認されている。*8

\section{結果}

採集尾数と体長・体重・年令組成 採集した堆マイワ シ成魯の尾数は 169 尾であった。採集時刻每にみると 18 時台, 19 時台, 20 時台および 21 時台でてれぞれ， 17 尾，81 尾，48 尾就よび 23 尾であった。採集時刻每

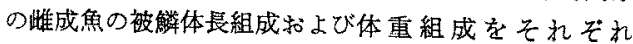
Fig. 2, Fig. 3 に示した。被鱗体長は，総採集試料では $17.6 \sim 22.2 \mathrm{~cm}$ の範囲で，0.5 cm 間隔の度数分布に怙汁 るモードが 19.0 19.5 cm であった。また，被鱗体長組 成は，18 時台のbのを除き採集時刻によって大きな違 いはなかった。体重は，総採集試料では 55.3 153.7 g の範围で，10g 間隔の度数分布に持けるモードが 80〜

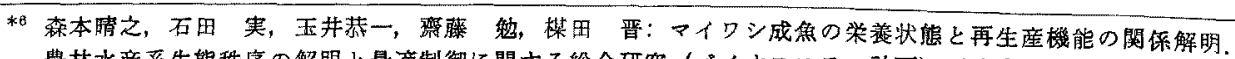
農林水産系生態秩序の解明と最遒制御に関する総合研究 (バイオコスモス計画) 平成 2 年度研究報告，176177 (1991). 

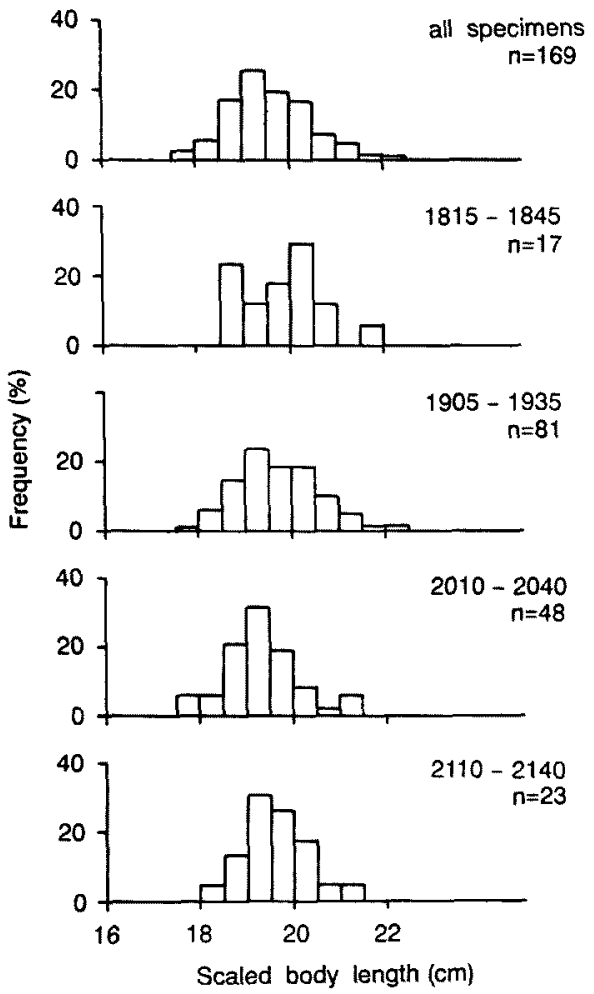

Fig. 2. Scaled body length frequency distributions for female Japanese sardines from Tosa Bay, southwestern Japan sampled at different times of day in November 1990.

The upper values in the figure indicate the time of sampling.

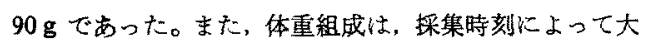
きな違いはなかった。年令組成は，1藏，2 歳， 3 歳お よび 4 藏以上がそれぞれ 8\%，29\%，50\% 杍よび $13 \%$ を占めた。

GSI と卵集水分含有帏の成係採集した睢成魚 169 㑭体のうち 154 個体の GSI 之即栄水分含有率の関係老

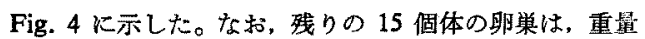
が $1 \mathrm{~g}$ 末満と少量であったために水分含有率測定が困難 であった。GSIは 1.1 から 15.6 の範团で，畉栄水分含 有率は 66.2\% から 91.6\% の籍聿であった。そして，卵 雀の水分含有率は, GSI か 4 以下では大部分 $80 \%$ 以下 で, GSI が 4 から 6 の間は 70\% 前後もしくは $89 \%$ 前 後て、GSI が 6 以上では 89\% 前後と高い值を示した。 水分含有率が約 $80 \%$ 以下の卵巣恃，成熟過程の卵巣, もしくは産卵後の卵菓ですり，89\% 前後の卵巣は吸水 中の畉母細胞や吸水を完了した卵母細胞，もしくは非卵 した卵を保有する卵宩であった。
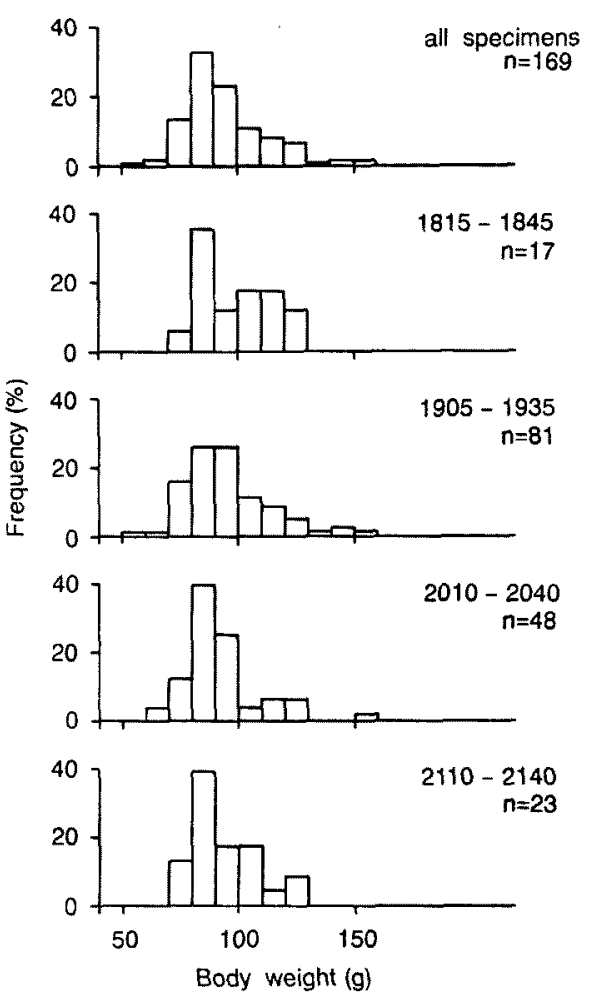

Fig. 3. Weight frequency distributions for female Japanese sardines from Tosa Bay, southwestern Japan sampled at different times of day in November 1990.

The upper values in the figure indicate the time of sampling.

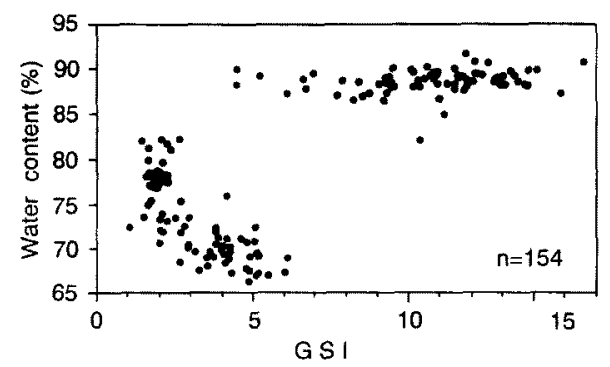

Fig. 4. Water content in ovaries of female Japanese sardines sampled from Tosa Bay, southwestern Japan in November 1990 in relation to gonadosomatic index (GSI). GSI, 100 (weight of ovary/total body weight).

GSI の頻度分布およびその経時変化採集した踓成 魚の GSI の頻度分布を Fig. 5 に示した。この図では卵 单を最も成愁の進んだ卵母細胞の状熊から，(1)吸水中の 


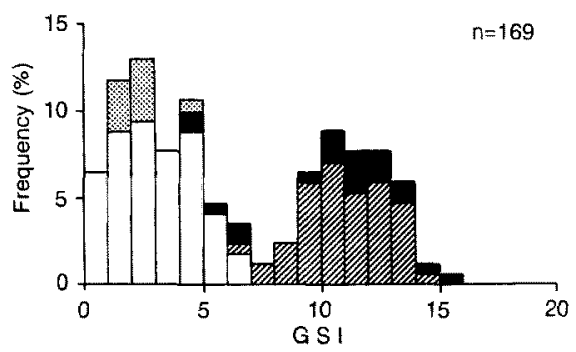

Fig. 5. Frequency distribution of gonadosomatic index (GSI) values for female Japanese sardines sampled from Tosa Bay, southwestern Japan in November 1990.

The histogram representing the frequency of GSI values is subdivided to show the frequency of ovaries before hydration (open area), under hydration (striped area), after ovulation (solid area), and under spawning (stippled area). GSI, 100 (weight of ovary/total body weight).

畉母細胞を保有しない、卵栄，(2)吸水中の䛇母細胞を保有

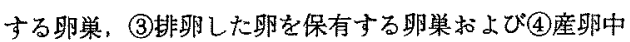
の卵巣（僅が排卵した卵母細胞を保有する卵巣）の 4 群暗践して示した。ヒストダラムの形状仕 2 峰型を示 ᄂ, GSI が 2 以上 3 末满と 10 以上 11 未满飞モード があり，GSI が 6 8 の個体の割合は極めて低かった。 そして，GSI と卵巣の成熟状態の関係をみると，吸水中 の莭細胞を保有しない畉巣は GSI が $0 \sim 6$ の䇺囲に， 吸水中の卵母細胞を保有する卵巣は GSI が 6 14 の範 囲に，排卵した卵を保有する卵巣は GSI が 4 15 の範 囲に，拉上び産卵中の卵巣は GSI が 1 4 の範囲にみら れた。

次に, GSI の頻度分布の経時変化を Fig. 6 亿示した。

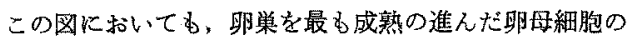
状態から，Fig. 5 々同様化 4 群化識別して示した。吸水 中の卵母細胞もしくは排卵した卵を保有する雌で主炕構 成される GSI が 6 以上の個体の割合は，18 時台，19 時 台, 20 時台お上び 21 時台の採集個体で，それぞれ $59 \%$ 。 $52 \% ， 44 \%$ 㸱よび 17\% と経時的低くなり，21 時台の 採集個体ではその割合が著しく低下した。そして、これ ら GSI が 6 以上の個体の眨巣の成熟状態は，21 時前後 て大大く変化し，21 時以前の採集個体では吸水中の卵 母細胞を保有する卵巣が比較的多くみられたが，21 時 台の俫集個体では吸水中の卵舟細胞を保有する卵巣はる られず，排卵した卵を保有する畉栄のみが微察された。

一方, GSI が 1 以上 2 末满の個体の割合は, 18 時台, 19 時台, 20 時台拉上び 21 時台の採集個体で，それぞ れ 0\%，6\%，13\% 敊よび 39\%で，21 時台の採集個体 では先の割合が著しく高くなった。そしてこれらの卵

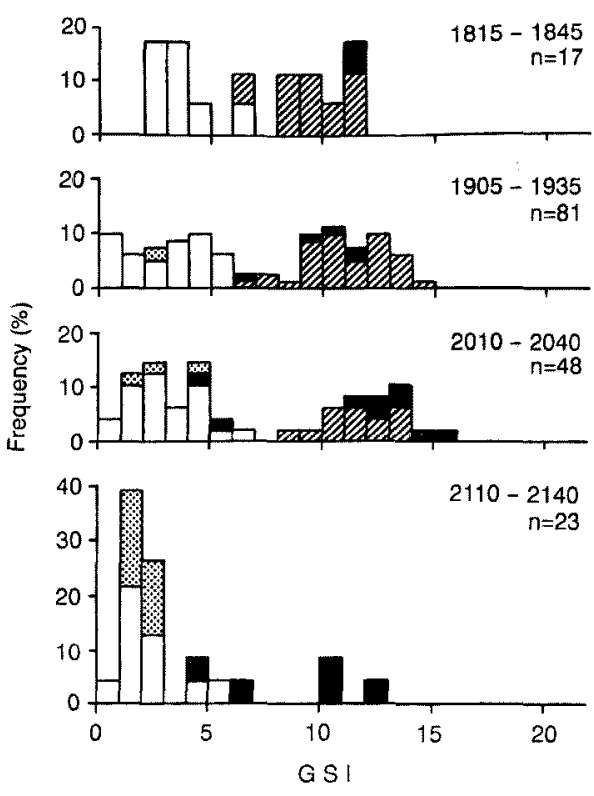

Fig. 6. Frequency distributions of gonadosomatic index (GSI) values for female Japanese sarrdines from Tosa Bay, southwestern Japan sampled at different times of day in November 1990 .

The upper values in the figure indicate the time of sampling. The sets of histograms representing the frequency of GSI values are subdivided to show the frequency of ovaries before hydration (open area), under hydration (striped area), after ovulation (solid area), and under spawning (stippled area). GSI, 100 (weight of ovary/total body weight).

杪の成熟状態は，21 時前後で大きく変化し，21 時台の 採集個体では産町中の個体の㲅合が著しく高くなった。 この傾向は GSI が 2 以上 3 末満の個体についても同様 であった。このよらに，GSI の頻度分布は 21 時を境と して有意心変化した $(P<0.05, U$-検定)。

吸水雌および排卵雌の個体数の雌全個体数に占める割 合の経時変化 吸水雌和よび排莭崔の個体数の崔全個体 数に占める割合の経時变化を Table 1 K示した。吸水放 の割合は 18 時台, 19 時台, 20 時台叔よび 21 時台の 採集個体でてれでれ 47.1\% (17 個体中 8 個体)，45.7\% (81 個体中 37 個体)，27.1\%（48 個体中 13 個体）捄よ び 0\% (23 個体中 0 個体)で，20 時以降に低くなった。 排耶㳩倠の割合は, 18 時台，19 時台，20 時台および 21 時台の採集個体でそれぞれ 5.9\%（17 個体中 1 個体)， $6.2 \%$ (81 個体中 5 個体)，18.8\% (48 個体中 9 個体) 括上ぴ 21.7\%（23 個体中 5 個体）で, 20 時以降に高く 
Table 1. Percentage of female Japanese sardines with hydrated oocytes and ovulated eggs from Tosa Bay, southwestern Japan sampled at different times of day in November 1990

\begin{tabular}{cccc}
\hline Time & $\begin{array}{c}\text { Females } \\
\text { with } \\
\text { hydrated } \\
\text { oocytes } \\
(\%)\end{array}$ & $\begin{array}{c}\text { Females } \\
\text { with } \\
\text { ovulated } \\
\text { eggs } \\
(\%)\end{array}$ & $\begin{array}{c}\text { Total } \\
\text { no. } \\
\text { of } \\
\text { females }\end{array}$ \\
\hline $1815-1845$ & 47.1 & 5.9 & 17 \\
$1905-1935$ & 45.7 & 6.2 & 81 \\
$2010-2040$ & 27.1 & 18.8 & 48 \\
$2110-2140$ & 0 & 21.7 & 23 \\
\hline
\end{tabular}

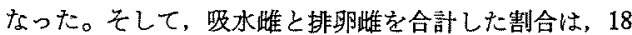
時台，19 時台および 20 時台の棌集個体では，それぞれ 53.0\%，51.9\% および 45.9\% と若千低下したが，大さ な变化は見られなかった。しかし，21 時台の採集個体で はその割合が $21.7 \%$ と急激に低下した。

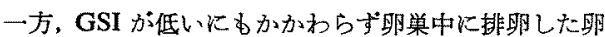

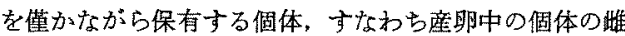
全個体数に占める割合は，18 時台，19 時台，20 時台拉 よび 21 時台の採集個体でそれぞれ 0\%（17 個体中 0 個 体)，2.5\%（81 個体中 2 個体)，6.3\%（48 個体中 3 個 体) 和上び 30.4\%（23 個体中 7 個体）で，21 時以降に 著しく高くなった。

\section{吸水過程にある卵母細胞を保有する卵巣の水分含有率}

の経時変化 吸水過程飞ある卵母細胞を保有する卵巣の 水分含有率が採集時刻に上ってどの程度異なるかどらか を調べ，Table 2 に示した。な扎ここでの助栄には， 排卵した卵をもつ卵策も含む。18 時台, 19 時台, 20 時 台怙よび 21 時台に採集乙た個体の卵巣水分含有率は，

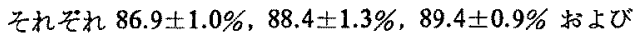
$89.1 \pm 0.7 \%$ で，20 時台に採集した個体の畉栄水分含有 率は 18 時台および 19 時台のそれらに此へて，有意に 高かった（それそれ $P<0.001 ， P<0.005 ， t$-検定）。そし て，20 時台と 21 時台に採集した個体の畉巣水分含有率 には有意差が見られなかった。このことから，卵母細胞 の吸水は 20 時前後まで進行し，20 時前後に完了したと 考えられた。

吸水過程にある卵母細胞中の㽗黄体積の経時变化 吸 水過程にある莭母細胞中の卵黄体積の経時変化を Table 3 に示した。なお，ここでの卵巣には，誹した即をる つ卵鉴る含も。18 時台, 19 時台, 20 時台およびに 21 時 台に採集した個体の吸水過程にある卵母細胞中の卵黄体 䞍は，それぞれ 3.72 $0.52 \times 10^{-1} \mathrm{~mm}^{3}, 3.99 \pm 0.49 \times 10^{-1}$ $\mathrm{mm}^{3}, 4.52 \pm 0.52 \times 10^{-1} \mathrm{~mm}^{8}$ および $4.38 \pm 0.36 \times 10^{-1}$ $\mathrm{mm}^{8}$ で，20 時台に採集した個体の吸水過程にある䀣母 細胞中の䀦黄体積は，18 時台扣よび 19 時台の採集個体 のそれらに比べて，有意に大きかった（共に $P<0.001$ ，
Table 2. Water content of the ovaries in Japanese sardine females with hydrated oocytes and ovulated eggs from Tosa Bay, southwestern Japan sampled at different times of day in November 1990

\begin{tabular}{ccc}
\hline Time & $\begin{array}{c}\text { Water content } \\
\text { of ovaries } \\
(\%)\end{array}$ & $\begin{array}{c}\text { Total no. } \\
\text { of ovaries }\end{array}$ \\
\hline $1815-1845$ & $86.9 \pm 1.0$ & 9 \\
$1905-1935$ & $88.4 \pm 1.3 \mid * 2$ & 42 \\
$2010-2040$ & $89.4 \pm 0.9=$ & 22 \\
$2110-2140$ & $89.1 \pm 0.7$ & 5 \\
\hline
\end{tabular}

Values of water content are given as meant S.D.

$* 1 \quad P<0.001, * 2 \quad P<0.005$ ( $t$-test).

Table 3. Yolk volume of hydrated oocytes and ovulated eggs in the ovaries of female Jananese sardines from Tosa Bay, southwestern Japan sampled at different times of day in November 1990

\begin{tabular}{ccc}
\hline Time & \multicolumn{1}{c}{$\begin{array}{c}\text { Yolk volume } \\
\left(\times 10^{-1} \mathrm{~mm}^{3}\right)\end{array}$} & $\begin{array}{c}\text { Total no. } \\
\text { of ovaries }\end{array}$ \\
\hline $1815-1845$ & $3.72 \pm 0.52$ & $*$ \\
$1905-1935$ & $3.99 \pm 0.49$ \\
$2010-2040$ & $4.52 \pm 0.52$ & 9 \\
$2110-2140$ & $4.38 \pm 0.36$ & 22 \\
\hline
\end{tabular}

Values of yolk volume are given as mean \pm S.D. of 50 oocytes or eggs of each ovary. ${ }^{*} P<0.001$ ( $t$-test),

$t$-䎧定)，そして，20 時台之 21 時台に採集した個体間で は有意差が見られなかった。并して，この吸水過程にあ る卵母細胞の明黄体積の增加傾向は卵楽の水分含有率の 增加㑯向とよく一致した。

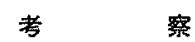

マイワシの産睢時刻について, 伊東ら ${ }^{11} 1$ は, 能登半島 近海で採集した畉の発生 stage，採集時刻执よび発生速 度から，20時から 24 時の間で，特に集中的《産卵が行 われるの生 20 時から 22 時をでの時間带であると推定 している。California sardine Sardina caerulea におい てむ, 同様の方法で，産卵は 20 時加ら 24 時の 4 時間

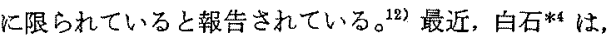
産矂親魚を用いて内分汹学的心産卵時刻を推定し，薩南 海域で採集したマイワシでは，最終成熟・排卵から座卵 の過程で短時間に分泌される卵成熟誘起ステロイドホル モンの血中量が 20 時から 23 時の間に高くなり, 本海域 に括るるイワシの産卵時刻は 20 時から 23 時の間で あると推定している。また，松浦放は，同海域に括ける マイワシの産卵時刻について，3〜4 時間間融で採集した 産畉視魚の各成熟ステージの出現率の变化から, 20 時か ら 23 時の間であると推定している。本研究では，産畉 時刻を直接的に求める手法の1つとして，採寨した産卵 
期成䱕の GSI の頻度分布の経時変化や吸水政和よび排

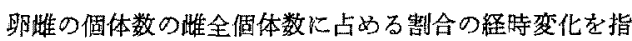
標として用いた。そして，19時 5 分から 19 時 35 分の 間に採集した試料之 20 時 10 分から 20 時 40 分の間に 採集した試料とで，両指標が若干变化し，20 時台に産畉 を行った個体るわずかながらみられたと考えられるが， 20 時 10 分から 20 時 40 分の間に採集した試料之 21 時 10 分から 21 時 40 分の間に採集した試料とで雨指摽が 大きく变化したことは，廉率がその間の 21 時前後の極 わて短時間に大規模に開始されたことを示すと考光られ る。また，GSI が低いにもかかわらず卵巣中に排した 畉を僅かながら保有する個体，すなわら産卵中の個体の 割合が 21 特以降に急激に高くなったことは，そのこと

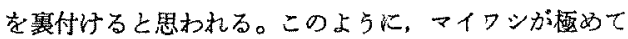

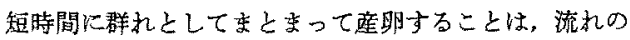
比較的強い環境下に颃いて，受精の成功率を高める戦略 の一らと考えられる。

この 21 時という産卵開始時刻は，伊東らの推定した 應卵時間带である 20 時から 24 時和上び白石や松浦の 推定した 20 時から 23 時の間にあてはまったが，伊東 らの調查が日本海で 5 月に，白石や松浦の調疽が薩南海 城で 2 3 月に，今回の調查が土佐湾で 11 月に行われ たことを考慮すると、マイワシの産卵時刻は地域的・時 期的にむまり影艟されず，種固有のすのであると推察さ れる。しかし，カタクチイワシの場合，産卵眭刻の決 定は明期の終了時刻牦和っていることが知られてい

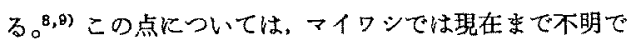
あり，今後，明期の終了時刻が異なる採集日の個体を用 いて検討する必要がある。また，伊東らの調查が 1950 年代でマイワシ資源の低水準期で行われ，著者の調查や 白石，松浦の調查が近年の資源高水倠期に行放れたこと

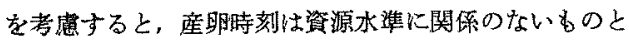
思われる。

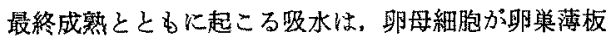
から卵栄察に離脱する，いかゆる排卵を誘起する一要因 であることが知られている。帛-18) 吸水が完了し，排卵さ れた卵が，座卵されるまで体内に保持される時間恃魚種 に上って大きく異なることが知られている。ニシマス Oncorhynchus mykiss では排卵後 1 2 週間体内に保持 され，18) 18〜20日後です正常な眆が産出されるとい $5 。{ }^{20)} 7=$ Plecoglossus altivelis ${ }^{21)}$ やマガレイ Pleuronectes yokohamae ${ }^{18]}$ では 1 2 日, マダイ Pagrus

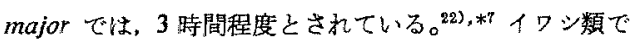
は，カタクチイワシについての報告があり，吸水過程を 完了し，排卵してから，偟卵するまでに要する時間が極
わて短いことが知られているが, 8,8) その保持時間につ いては垠告されていない。マイワシに怙いては，今回の

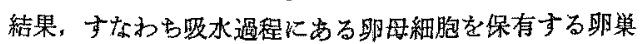
の水分含有率の経時変化から，卵母細胞の吸水は 20 時 前後に完了したと考えられ，また，産䀦開始時刻が 21 時前後であったことから，吸水過程を完了してから産䛇 するまでに要する時間が約 1 時間であると考克られた。 このように，、イロンは，吸水を完了してから非邪を経 て産卵するまでの時間が他鿭種に比へてて短かいことが同 えた。これまでに，産卵適水温が高い魯種ほど，排卵後 速やかに鷹卵しないと発眼率の低下が起こることが知ら れている。吾) 今回マイワシ産卵親魚を採集した海域の魚

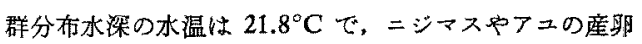
適水温とされている $10 \sim 12^{\circ} \mathrm{C}$ 就よび $15 \sim 16^{\circ} \mathrm{C}$ に比べ 高水温であったため，㥸水を完了し，排卵後，速やかに 産卵したのかむしれないてそして、このことは，11月の 土佐管に和けるマイワシの埸合，吸水完了個体や排㽗個 体を採集でさる時間が非常に短いことを示している。

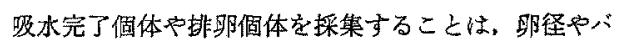
ッ産畋などの再生廒能力を求め，そ九らを比較する 研究に括いて重要である。

一般に魚類では，放卵された時の卵サイズが大きけれ

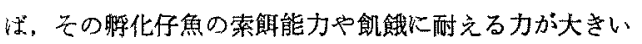
とされて拉り，24) 大西洋ニシン Clupea harengus では卵 サイズと餒化時の渎の体長や前期仔魚時の成長量の間 に正の相関関係があることが知られている。尚) 今回の結 果では，卵黄体積は吸水過程においては有意に增加し， 吸水が完了すると一定となった。一般に, 硬骨魚類で は, 眀母組胞の容積や湿重量は吸水によって 3〜4 倍に 增えるが、26) その较燥重量は吸水前後でほとんど变化し

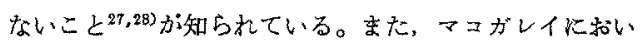
ては，畞母細胞の吸水量は畉黄球の吸水量にほ注等しい

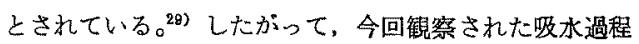
に和ける眀黄体積の增加は栄着物が供給されたためでは

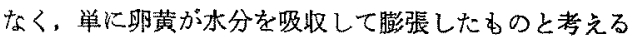
のが妥当であるが，卵黄の大きさと扸化仔魚の成長量や 柃餓酎性との関係を検討する時, 四黄の大きざの增加が 停止した，吸水完了の個体变用いることは必須と考えら れる。

そして今回，吸水過程にある卵母細胞を保有する卵巣 の水分含有率が採集時刻の總過とともに增加し，89\%前 後で一定になったことは，マイワシに括いては，莭勫

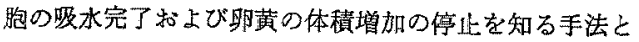

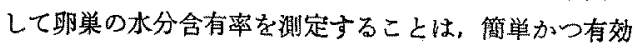
であり、その指標として水分含有率 $89 \%$ を用いること

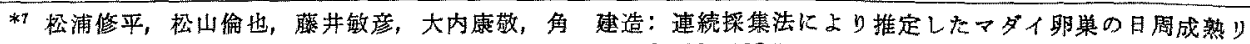
ズム、昭和 59 年度福岡水産試歌場研究業弱報告, 125-130 (1984). 
ができると考えられる。

吸水雌や排卵崔を採集することは，多回産卵魚のバッ

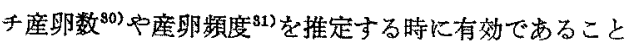
が知られている。今回採集した踓成魚に扣いて，蔇の 水分含有率が $89 \%$ 前後に達して，卵母細胞の昅水を法 ほ完了したと考竞られる個体の GSI が, 4.5 から 15.6 の幅をもった。このことから、バッ産卵数の個体差 は，かなり大きいるのであることは予想され得る。亦

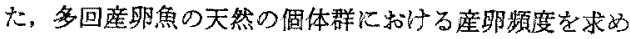
る方法の1つとして，吸水雌怙よび排卯雌の個体数の雌 全個体数に占める割合から産卵頻度を定量的に推定する といら方法がある。洌えば，吸水雌和上び排畉雌の個 体数の雌全個体数に占める割合が $20 \%$ ならば，産卵は $5(=100 / 20)$ 日に 1 回行われるといら理論である。この 方法によると本研究のマイワシ個体群では，その割合が 約 50\%であったことから，産卵が 2 日に 1 回行われる ことになる。しかし，毛しそうなら，卵母細胞が睖水し ていない残りの $50 \%$ の雌の卯策の成熱状態の足並が揃 っていなければならないが，実際には，GSI 組成や卵栄

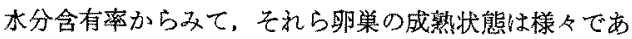
った。このことから、マイワシ産甽群は約半数が同調的

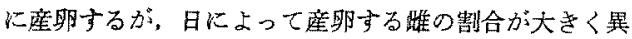
なると予想される。したがって、マイワシの産卵頻度を 正確に求めるためには，膺卵期間中に同一個体群を対象 に何日にもわたる連続した採集調查が必要である。

\section{謝辟}

本研究の遂行およびとりまとめにあたり有益な助言と 議諭を頂いた，南西海区水産研究所小坂 淳博士，花岡 藤雄氏（1992．3．退官），小西芳信氏(現西海区水産研 究所)，広田裙一博士，石田実氏，王井恭一博士に， た，数々の分析に赫いて，御協力を頂いた同研究所吉本 淳氏に感謝の意を表する。また，マイワシ成魚採集調査 に御協力いたたいた高知県水産試臨場察田敏文場長 (1991. 3. 退官)，松木征史氏並びに米田実氏，高知綮 土传海洋丸沖㳊和人船長をはじあ乗組員の力ヶに心から 御礼申し上げる。本研究の一部は科学技術庁科学技術振 興調整費重点基礎研究の一環として行われた。記して関 係各位に御礼申し上げる。

\section{文献}

1) F. N. Clark: Maturity of the california sardine (Sardina caerulea), determined by ova diameter mesurements. Calif. Div. Fish Game, Fish Bull, 42, 1-49 (1934).

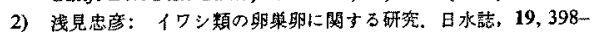
404 (1953).

3) 石田力一, 㜔川正期, 有田穊子：マイワシ Sardinops meianosticta (Temminck \& Schlegel) の库卯回教にっいて(予報). 北 水研埌, 20, 139-144, 2PLS (1959).

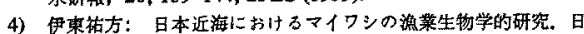

水研焃，9，143-161 (1961).

5) 宇作美传造：日本産マイワシ Sardinops melanosticta (T. \&

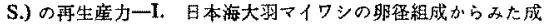
热上期数. 来海水研報, 38, 1-30, 1 PL (1964).

6) J. R. Hunter and B. J. Macewicz: Sexual maturity, batch fecundity, spawning frequency, and temporal pattern of spawning for the northern anchovy, Engraulis mordax, during the 1979 spwning season. Callf. Coop. Oceanic Fish. Invest. Rep., 21, 139-149 (1980).

7) J. R. Hunter and R. Leong: The spawning energetics of female northern anchovy, Engraulis mordax. Fish. Bull., U. S., 79, 215-230 (1981).

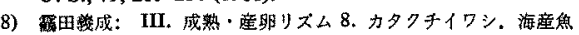
の成熟・産䁒りズム（日本水夝学会編）水産学シリーズ 85, 恒 星社謜生閣, 苯京, 1991, pp. 101-112.

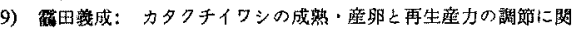
与万研究。水工研報，13，129-168 (1992).

10) M. Matsuyama, S. Adachi, Y. Nagahama, C. Kitajima, and $S$. Matsuura; Annual reproductive cycle of the captive female Japanese sardine Sardinops melanostictus: relationship to ovarian development and serum levels of gonadal steroid hormones. Mar. Biol., 108, 21-29 (1991).

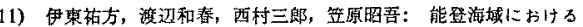

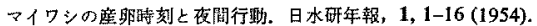

12) E. H. Ahlstrom: Studies on the Pacific pilchard or sardine (Sardinops caerulea) 4. Influence of temperature on the rate of development of pilchard eggs in nature. U. S. Dept. Interior, Fish and Wildifife Service, Spec. Sci. Rept., 23, 1-26 (1943).

13) J. R. Hunter and S. R. Goldberg: Spawning incidence and batch fecundity in northern anchovy, Engraulis mordax. Fish. Bull, U. S., 77, 641-652 (1980).

14) G. D. Stauffer and S. J. Picquelle: Estimate of the spawning biomass of the northern anchovy central subpopulation for the 1980-81 fishing season. Calif. Coop. Oceanic Fish. Invest. Rep., 22, 8-13 (1981).

15) J. Alheit, V. H. Alarcon, and B. J. Macewicz; Spawning frequency and sex ratio in the Peruvian anchovy, Engraulis rigens. Calif. Coop. Oceanic Fish. Invest. Rep., 25, 43-52 (1984).

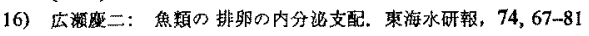
(1973).

17) K. Hirose, T. Hirano, and R. Ishida: Effects of salmon gonadotropin on ovulation in the ayu, Plecoglossus altivelis, with special reference to water balance. Comp. Biochem. Physiol., 47A, 283-289 (1974).

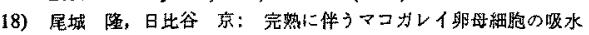

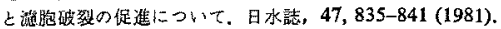

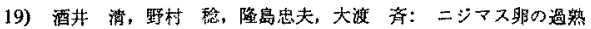

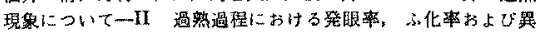

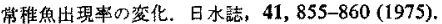

20）野村 稳，酒井 消，隆岛忠夫：三ジマス的の過㷫現泉につい

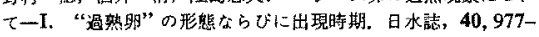
984 (1974).

21) K. Hirose, R. Ishida, and K. Sakai: Induced ovulation of ayu using human chorionic gonadotropin (HCG), with special reference to changes in several characteristics of eggs retained in the body cavity after ovulation. Bull. Japan. Soc. Sci. Fish., 43, $409-416$ (1977).

22) M. Matsuyama, S. Adachi, Y. Nagahama, and S. Matuura: Diurnal rhythm of oocyte development and plasma steroid hormone levels in the female red sea bream, Pagrus major, during the spawning season. Aquaculture, $73,357-372$ (1988).

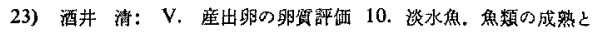

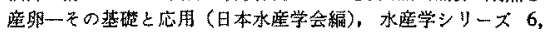
桓星社境生閣, 来京, 1974, pp. 100-112.

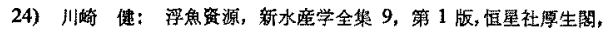
東京, 1982, pp. 141-151.

25) J. H. S. Blaxter and G. Hempel: The influence of egg size on herring larvae (Clupea harengus L.), J. du. Cons., 
28, 211-240 (1963).

26) T. W. Fulton: On the growth and maturation of the ovarian eggs of the teleostean fishes. Annu. Rep. FIsh. Board Scotl., 16, 88-124 (1898).

27) F. LeClus: Dry mass yolked oocytes of the South West African pilchard Sardinops ocellata in relation to maturity stages and spawning cycles, 1972-1974. Investl. Rep. Sea Fish. Brch. S. Afr., 119, 1-29 (1979).

28) M. S. Greeley Jr, H. Hols and R. A. Wallace: Changes in size, hydration and low molecular weight osmotic effectors during meiotic maturation of Fundulus oocytes in vivo. Comp. Biochem. Physiol, 100A, 639-647 (1991).

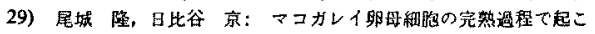

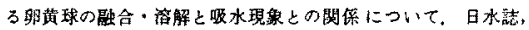

47, $1123-1130(1981)$

30) J. R. Hunter, N. C. H. Lo, and R. J. H. Leong: Batch fecundity in multiple spawning fishes, in "An egg production method for estimating spawning biomass of pelagic fish: Application to the northern anchovy, Engraulis mordax" (ed. by R. Lasker), U. S. Dep. Commer., NOAA Tech. Rep. NMFS, 36, 67-77 (1985).

31) J. R. Hunter and B. J. Macewicz: Measurement of spawning frequency in multiple spawning fishes, in "An egg production method for estimating spawning biomass of pelagic fish: Application to the northern anchovy, Engraulis mordax" (ed, by R. Lasker), U. S. Dep. Commer, NOAA Tech. Rep. NMFS, 36, 79-94 (1985).

Nippon Suisan Gakkaishi : Formerly Bull. Japan. Soc. Sci. Fish. 